\title{
Challenges in the Posting and Transfer of Teachers to Rural Community Schools in the Sissala East Municipality
}

\author{
Majeed Salifu \\ Tumu College of Education, Post Office Box 19, Tumu. UWR
}

\begin{abstract}
The effective posting and transfer of teachers is a linchpin in getting teachers to rural school locations. This study explored the challenges faced by the Sissala East Municipal Education Directorate in posting and transfer of teachers to rural schools. It further looks at the effects of inadequate teachers in rural schools and proposes strategies to engender the posting and transfer of teachers to rural schools. The concurrent triangulation design type of the mixed method research paradigm was employed for the study. Both qualitative and quantitative data were collected simultaneously. Two hundred and sixty (260) respondents were sampled for the study through simple random, stratified and purposive sampling techniques. The data were collected using a questionnaire (fivepoint Likert scale) and a semi-structured interview guide. The collected data sets were analysed using SPSS software version 20. The study found that teacher accommodation, professional development needs, perceived ignorance about rural dwellers and condition as well as branding rural teachers as "village teachers", teachers desire to live in urban areas, Ministry of Education recruitment practices, the desire of graduate teachers to teach in senior high and urban schools, contribute significantly to the challenge of posting and transfer of teachers to rural schools. On the effects of inadequate teachers, the study found the practice of multigrade teaching, heavy workload on teachers, the presence of unqualified teachers and the inability to cover the curriculum On strategies in attracting and retaining teachers in rural schools, the study found the following strategies: recruiting teachers from targeted rural areas, induction of new teachers, provision of financial incentives and siting of teacher training institutions in rural areas. The study, contrary to previous research findings found that force transfer of teachers should be enforced. The study concluded that the Sissala East Municipal Education Directorate is challenged in the posting and transfer of teachers to rural schools. The study recommended the provision of decent accommodation for teachers, giving priority to rural teachers in granting of study leave, provision of social amenities in rural areas, decentralizing recruitment of teachers, provision of financial incentives and induction of new teachers.
\end{abstract}

Keywords: posting, transfer, urban, rural and community

DOI: $10.7176 / \mathrm{JEP} / 11-36-13$

Publication date: December $31^{\text {st }} 2020$

\section{Introduction}

The posting and transfer of staff in organizations, institutions and other forms of establishments is a worldwide phenomenon. This practice is not devoid of the education sector. In the education sector continuing teachers, newly recruited teachers, teachers returning from further studies, teachers returning from secondment (that is teachers permitted to work with other institutions) and teachers who broke service and are re-engaged are posted to schools and other management units. In the same vein, practicing or continuing teachers are transferred from one school to the other.

Posting and transfer of employees are necessary in organizations. Transfers help minimise politics between employees, ensure cordial relationship between employees, increase transparency in work, obviate syndicate of employees for unethical purposes and obviate nepotism in organisations (Yoder \& Other, 1958 as cited in Hassan, 2016). In organisations where transfers are infrequently done, it may lead to the creation of informal groups by employees. This state of affairs may lead to secrecy in the flow of work and lack of transparency in work. It may also lead to organizational politics among employees, fall in coordination between employees and eventual drop in overall organizational performance (Yoder \& Other, 1958 as cited in Hassan, 2016). Notwithstanding the positive undercurrents of posting and transfer of employees, haphazard posting and transfer of employees can negatively affect an organization's productivity level. This situation results when high skilled employees are transferred leaving novice employees (Hassan, 2016). Frequent transfer of teachers especially within the academic year without quick replacement, could affect academia and thus, not necessary when both the outgoing and the incoming teachers have the same philosophy (Noor, Ishaque, Lodhi, \& Memon, 2012). Posting of teachers ensures that teachers are deployed based on the need of schools as well as the skills and specialization of teachers.

The transfer of teachers is done on request or through administrative action (Noor, Ishaque, Lodhi, \& Memon, 2012). Transfer instigated by a teacher is termed as voluntary transfer. A variety of reasons inform teacher voluntary request for transfer. These reasons, among others, include the need to work in a school closer to home, personal conflict with the headteacher or other staff members, change of environment and avoidance of involuntary transfer by education administrators (Noor, Ishaque, Lodhi, \& Memon, 2012). Other factors influencing teacher 
choice of school are the availability of educational facilities for children, the cost of living, employment opportunities for spouse, proximity to friends as well as family and availability of cultural and professional facilities (Barry \& Terence, 1976).

A transfer initiated by education administrators is termed as involuntary transfer. This form of transfer may be occasioned by the need to move a teacher who is not fit for a school or performing unsatisfactorily. It is also brought about to resolve teacher imbalances in schools due to changes in student enrollment, academic programmes among other reasons (Noor, Ishaque, Lodhi, \& Memon, 2012). Involuntary transfers lead to equity in the distribution of teachers and for that matter, quality teachers across schools. Posting and transfer of teachers could bring about sending teachers to schools where their particular set of skills will make a more positive impact. Besides, it could enable education authorities to transfer low-performing teachers out of low-performing schools (Jason, Susanna \& Nathaniel, 2012). The practice may also lead to teachers working harder when transferred out of unsatisfactory performing schools. This is possible through the influence of a new school environment that encourages extra efforts by teachers (Jackson \& Bruegmann, 2009). Involuntary transfer also increases teacher enthusiasm and the use of new techniques; it enlarges teacher perspectives on student development and district needs, self-examination and change in the receiving school and increases dialogue and sharing of ideas among teaching staff (Lynne, \& Nancy, 1985).

Alternatively, equity in the posting and transfer of teachers could be undermined if an involuntary transfer results in a mismatch of teacher skills and student needs. This thus hurts teacher productivity. Besides, this kind of transfer may decrease teachers' post-transfer effort, if found demoralizing or discouraging (Jason, Susanna \& Nathaniel, 2012). It could also lead to teacher distrust, burdensome preparation time, practical problems of time and money to travel to a new school and mutual adjustment difficulties between teachers and community members (Lynne, \& Nancy, 1985).

Transfer of personnel in the education sector takes the form of intra and inter transfers. Intra metropolitan, municipal and district transfers, represent transfers within the aforementioned levels of education directorates. On the other hand, transfers involving the movement of personnel from one metropolitan, municipal, regional and district to the other are termed as inter transfers. Inter metropolitan, municipal, regional and district transfers are normally voluntary. They are effected based on request by teachers. In effecting involuntary intra transfers, care must be taken to blend quality and ineffective teachers. When quality teachers are transferred out of a school and the opposite caliber of teachers are transferred in, it often affects efforts to offer meaningful staff development, build a sense of mission, and foster a mutual atmosphere among staff (Melinda, 2000).

\subsection{Statement of the Problem}

At all times, education directorates or administrators are confronted with the herculean task of addressing the shortage of teachers, overstaffing of schools, the balance between trained and untrained teachers in schools as well as rural and urban teacher imbalances. Posting and transfer mechanisms are normally employed to address the aforementioned challenges.

Ghana, as far back as 1969 , recognised the need for equitable deployment of teachers across the country. This recognition led to the introduction of policies and procedures for the posting of newly trained and qualified teachers purposely to engender equity across various regions of the country (Daniel, 1994). Further efforts were made in addressing, in particular, the imbalances in the number of teachers in rural and urban areas by engaging national service personnel who were posted to rural communities, newly trained teachers posted to rural areas and excess professional teachers transferred from education offices back to the classroom (Daniel, 1994).

In recent times, the educational reforms policy of 1987 equally recognised the importance of posting and transfer of teachers in an equitable manner. The reforms came with a comprehensive school mapping scheme with the view to identifying overstaffed schools to transfer teachers to understaffed schools. It establishes guidelines for staffing of schools at the basic education level.

Despite efforts made in addressing posting and transfer challenges in the education sub-sector, there still exist a myriad of challenges. Metropolitan, municipal, regional and district directorates of education are challenged in posting and transfer of teachers to disadvantaged rural schools.

The Sissala East Municipal Education Directorate, the focus of this study, is not devoid of posting and transfer challenges. The rate of teachers' request for transfer is far alarming. More than fifty percent (50\%) of intramunicipal transfers are normally targeted at the municipal capital, Tumu and its surrounding community schools which are about 24 kilometres away from Tumu. In the 2017/2018 academic year, out of seventy-six (76) intramunicipal transfer applications received at the municipal education office, forty-two (42) of the applicants sought transfer to the municipal capital, Tumu and nearby community schools. This represents fifty-five percent $(55 \%)$ of the total applications received (Sissala East Municipal Education Directorate, 2018). The glamour to teach in Tumu town and its surrounding community schools is frightening to the extent that teachers teaching in surrounding schools, about 24 kilometers away from Tumu, commute on daily bases from Tumu.

The challenge is more pronounced with the posting and transfer of female teachers. Virtually every female 
teacher wants to teach in Tumu town schools. Tumu township schools have a total teacher population of one hundred and eighty-one (181). Out of this number, one hundred and seventeen (117) are females. This represents sixty-five percent $(65 \%)$ of the total teacher population in Tumu town schools (Sissala East Municipal Education Directorate, 2018).

The emergence of a new crop of teachers, graduate teachers and those returning from further studies, in recent times, has exacerbated the already precarious posting and transfer situation of the Sissala East Municipal Education Directorate. Most graduate teachers allocated to the municipality, resist or evade posting to remote and distant communities.

The net effect of the posting and transfer challenges of the municipal directorate is the huge disparity in numbers of teachers, between schools in Tumu town and surrounding community schools on one hand and rural community schools on the other. A rural school such as Nabulo Basic School (which is made up of KG, primary and JHS) has a pupil enrolment of six hundred and two (602) with a corresponding teacher population of ten (10). This gives a pupil-teacher ratio (PTR) of 1:60 (Sissala East Municipal Education Directorate, 2018). In comparison, T.I. Ahmadiyya Basic School, an urban school in Tumu town, with the same three levels (KG, primary and JHS) has two hundred and six (206) pupils with eighteen (18) teachers. This gives a PTR of 1:11 (Sissala East Municipal Education Directorate, 2018). This disparity in teacher allocation is not different between other rural community schools and schools in Tumu town and surrounding communities. In nutshell teachers in the municipality resist, refuse or evade posting and transfer to rural schools.

It is for this problem that, the study explores the challenges encountered by the Sissala East Municipal Education Directorate in the posting and transfer of teachers to rural community schools in the Municipality with the view to proposing strategies to enhance the posting and transfer of teachers to rural schools.

The study hinges on the following research questions:

Research question 1: What are the factors leading to the understaffing of rural community schools in the Sissala East Municipal?

Research question 2: What are the effects of inadequate teachers in rural schools in the Sissala East Municipal? Research question 3: What are the strategies for effective posting and transfer of teachers to rural schools?

\subsection{Significance of the Study}

This study is significant for many reasons. In the first place, the study contributes to unearthing the setbacks in the equitable posting and transfer of teachers in the Sissala East Municipality in particular and Ghana as a whole. In this regard, the study proposes strategies to enhance the effective posting and transfer of teachers to rural schools.

Secondly, the study is expected to identify the pull and push factors accounting for teachers' obsession for Tumu town schools and their indifference for rural community schools respectively. This will enhance measures in various metropolitan, municipal, regional and district education directorates, to attract and retain teachers in rural schools.

In addition, the study is a contribution to the literature on education in Ghana especially on the posting and transfer of teachers. Researchers and students in education, therefore stand to benefit enormously from the literature. Furthermore, the study would help the human resource units of metropolitan, municipal, regional and district directorates of education, and that of the Sissala East Municipal Education Directorate, in particular, to improve upon posting and transfer of teachers.

Finally, the Ministry of Education and other policymakers in education could make use of the findings and recommendations of the study by formulating policies and guidelines on the posting and transfer of teachers in Ghana.

\subsection{Delimitation of the Study}

The subject of posting and transfer is a vast area and therefore, cannot be exhausted with a single study. This informed the delineation of the study which focuses on the challenges of posting and transfer of teachers to rural school locations. Posting and transfer of teachers is a global educational phenomenon. The media at the beginning of every academic year is normally inundated with issues of posting and transfer of teachers in the country. It is apt for this study to have assumed a national perspective. However, it is delimited to posting and transfer of basic school teachers by the Sissala East Municipal Education Directorate in the Upper West Region of Ghana, located in Tumu, the administrative capital of the Sissala East Municipal Assembly.

\subsection{Limitations of the Study}

A major restriction of this study is the likelihood of the respondents connected with the posting and transfer of teachers (human resource officers and members of the posting committee) of which the study centred on, providing inaccurate information. To remedy this situation, other respondents such as teachers who are directly affected by posting and transfer decisions were sampled for the study. These teachers as respondents were assured of confidentiality in handling information provided for the study. 
The accurate and truthful response of respondents to the questionnaire and interview schedule used was contingent on their mood at the time of filling the questionnaire and responding to the interview questions and thus could influence their responses. This was dealt with by seeking the consent and readiness of the respondents to respond to the questionnaire and interview queries.

The findings and conclusion of the study may be limited in scope. The findings and conclusion may not be generalised to cover other education directorates. This is because the challenges of posting and transfer of teachers may vary from one education directorate to the other. Notwithstanding these likely occurrences, the quality of work produced has not been compromised considering the safeguards put in place.

\section{Methodology}

This study employs the Concurrent Triangulation Design type of the Mixed Method research paradigm. This approach facilitates the collection and use of qualitative and quantitative data together. The two forms of data were collected simultaneously, merged and the results used to understand the research problem. This approach led to synthesizing ideas from both qualitative and quantitative research data (Johnson \& Onwuegbuzie, 2007).

The Sissala East Municipality has a total teacher population of eight hundred (800) at the basic school level. It also has thirty-one (31) teaching staff at the Sissala East Municipal Education Office. This gives a total teacher population of eight hundred and thirty-one (831) at the basic level and the Municipal Education Office. The table below presents the breakdown of the population on circuit and gender bases.

Table 1: The Number of Schools and Teacher Distribution per Circuit

\begin{tabular}{lcccc}
\hline Circuit & No. of Schools & $\begin{array}{c}\text { No. } \\
\text { Teachers }\end{array}$ & $\begin{array}{c}\text { of } \\
\text { No. of } \\
\text { Males }\end{array}$ & $\begin{array}{l}\text { No. of } \\
\text { Females }\end{array}$ \\
\hline Fachoboi & 5 & 36 & 33 & 3 \\
Nabulo & 4 & 33 & 27 & 6 \\
Kunchogu & 7 & 50 & 33 & 17 \\
Bujan & 6 & 75 & 50 & 25 \\
Tarsor/Kulfuo & 8 & 104 & 77 & 27 \\
Walembelle & 8 & 115 & 80 & 35 \\
Sakai & 8 & 112 & 68 & 44 \\
Tumu East & 11 & 130 & 57 & 73 \\
Tumu West & 10 & 145 & 50 & 95 \\
\hline Total & $\mathbf{6 7}$ & $\mathbf{8 0 0}$ & $\mathbf{4 7 5}$ & $\mathbf{3 2 5}$
\end{tabular}

\section{Source: Sissala East Municipal Education Directorate, 2018}

This study used a sample size of two hundred and sixty (260) teachers. Three different sampling techniques were used to sample respondents from the target population. Probability sampling techniques: the simple random and stratified sampling techniques were used to select respondents from the circuits. Purposive sampling technique, which falls under the non-probability sampling category, was used to select respondents at the Sissala East Municipal Education Office. Proportionate stratified random sampling technique was used in the selection of the male and female respondents. The numbers of male and female teachers vary considerably in some circuits. Samples were drawn based on the proportion of males and females in each circuit. Table 2 below presents the breakdown of the sampled respondents:

Table 2: Sample of the Study

\begin{tabular}{lccc}
\hline Unit & No. Sampled & Male & Female \\
\hline Education Office & 17 & 12 & 5 \\
Fachoboi & 27 & 25 & 2 \\
Nabulo & 27 & 22 & 5 \\
Kunchogu & 27 & 18 & 9 \\
Tarsor/Kulfuo & 27 & 20 & 7 \\
Bujan & 27 & 18 & 9 \\
Walembelle & 27 & 19 & 8 \\
Sakai & 27 & 16 & 11 \\
Tumu East & 27 & 12 & 15 \\
Tumu West & 27 & 9 & 18 \\
\hline Total & $\mathbf{2 6 0}$ & $\mathbf{1 7 1}$ & $\mathbf{8 9}$
\end{tabular}

Source: Field Data, 2019

This study was conducted using two instruments. A questionnaire and semi-structured interview schedule. Both instruments were used to gather data from teachers and frontline assistant directors and members of the municipal posting and transfer committee.

The concurrent triangulation approach was used in the interpretation of the overall results. This took into consideration the design used; the mixed method approach. The questionnaire data were analysed using the IBM 
Statistical Package for the Social Sciences (SPSS) version 20. The software enabled the generation of frequency distribution tables and percentages for interpretation. The data collected through interviews, short notes and audio recordings, were transcribed and categorised along with related themes of the research questions for interpretation (Patton, 2002). These analyses were done manually by the researcher. Both the questionnaire and interview data were integrated during the interpretation of the data (Terrell, 2011). The secondary data were subjected to content analysis.

\section{Results and Discussion}

Research question 1: Factors leading to the understaffing of rural community schools in the Sissala East Municipality.

The views of the respondents were sought on factors influencing the understaffing of rural schools. These factors cover poor housing, perception of disease attack, the quest for professional development, the tag 'village teacher', the desire to live in urban areas and bribery concerns. The views of the respondents on the above factors are presented in Table 3 below.

Table 3: Factors Leading to Understaffing of Rural Community Schools

\begin{tabular}{|c|c|c|c|}
\hline Factors & Scale & Frequency & Percentage $\%$ \\
\hline \multirow{5}{*}{$\begin{array}{l}\text { Teachers refuse posting and transfer to } \\
\text { rural schools due to poor housing }\end{array}$} & Strongly Agree & 123 & 47.3 \\
\hline & Agree & 100 & 38.5 \\
\hline & Undecided & 4 & 1.5 \\
\hline & Disagree & 25 & 9.6 \\
\hline & Strongly Disagree & 8 & 3.1 \\
\hline \multirow{5}{*}{$\begin{array}{l}\text { Teachers posted or transferred to rural } \\
\text { schools are susceptible to disease attacks }\end{array}$} & Strongly Agree & 19 & 7.3 \\
\hline & Agree & 56 & 21.5 \\
\hline & Undecided & 25 & 9.6 \\
\hline & Disagree & 95 & 36.5 \\
\hline & Strongly Disagree & 65 & 25.0 \\
\hline \multirow{5}{*}{$\begin{array}{l}\text { The quest for professional development or } \\
\text { further studies, inform teachers' refusal to } \\
\text { accept posting and transfer to rural } \\
\text { schools }\end{array}$} & Strongly Agree & 59 & 22.7 \\
\hline & Agree & 82 & 31.5 \\
\hline & Undecided & 26 & 10.0 \\
\hline & Disagree & 71 & 27.3 \\
\hline & Strongly Disagree & 22 & 8.5 \\
\hline \multirow{5}{*}{$\begin{array}{l}\text { Perceived ignorance about rural dwellers } \\
\text { and branding teachers as "village } \\
\text { teachers" contribute immensely to the } \\
\text { reluctance of teachers to accept posting } \\
\text { and transfer to rural schools }\end{array}$} & Strongly Agree & 61 & 23.5 \\
\hline & Agree & 90 & 34.6 \\
\hline & Undecided & 30 & 11.5 \\
\hline & Disagree & 46 & 17.7 \\
\hline & Strongly Disagree & 33 & 12.7 \\
\hline \multirow{5}{*}{$\begin{array}{l}\text { Teachers desire to live in large urban } \\
\text { areas and not rural areas underlines the } \\
\text { unwillingness of teachers to accept } \\
\text { posting and transfer to rural schools }\end{array}$} & Strongly Agree & 79 & 30.0 \\
\hline & Agree & 89 & 34.2 \\
\hline & Undecided & 12 & 4.6 \\
\hline & Disagree & 62 & 23.8 \\
\hline & Strongly Disagree & 18 & 6.9 \\
\hline \multirow{5}{*}{$\begin{array}{l}\text { The Ministry of Education recruitment } \\
\text { system, breeds patrimonialism, bribery } \\
\text { and other rent-seeking behaviours which } \\
\text { contribute to the understaffing of rural } \\
\text { schools }\end{array}$} & Strongly Agree & 103 & 39.6 \\
\hline & Agree & 79 & 30.4 \\
\hline & Undecided & 31 & 11.9 \\
\hline & Disagree & 33 & 12.7 \\
\hline & Strongly Disagree & 14 & 5.4 \\
\hline \multirow{5}{*}{$\begin{array}{l}\text { Graduate teachers and those returning } \\
\text { from further studies are to teach in senior } \\
\text { high schools and urban schools and not } \\
\text { rural schools }\end{array}$} & Strongly Agree & 17 & 6.5 \\
\hline & Agree & 15 & 5.8 \\
\hline & Undecided & 10 & 3.8 \\
\hline & Disagree & 92 & 35.4 \\
\hline & Strongly Disagree & 126 & 48.5 \\
\hline \multicolumn{2}{|l|}{ Total } & 260 & 100.0 \\
\hline
\end{tabular}

Source: Field Data, 2019

The results of the questionnaire in Table 3 above indicate that two hundred and twenty-three (223) respondents (representing 85.8\%) agreed that teachers refuse posting and transfer to rural schools due to poor housing whilst thirty-three (33) respondents (representing 12.7\%) disagreed with the statement. Four (4) of the respondents $(1.5 \%)$ were undecided in connection with the statement that teachers refuse posting and transfer to rural schools due to poor housing. 
In a face-to-face interview with a cross-section of the respondents, it became clear that the poor housing has been a repelling factor of most teachers from rural schools. In an attempt to describe the indecent nature of teacher housing in rural areas, this was how a teacher captured it:

Teacher accommodation in rural areas is nothing to write home about. I remember in my previous school, during the rural electrification exercise, Chinese contractors' in-charge of electrification of the community, refused to extend electricity to a teacher's quarters because they could not believe that human beings live in the building. They thought it was a pen.

It was further revealed in an interview that, teachers in the past were attracted to rural schools such as Dolibizon basic school, a rural community school, due to decent housing for teachers. This finding is in agreement with the finding of Moleni and Ndalama (2004), who argued that poor accommodation account for understaffing of rural and remote community schools.

The opinions of the respondents, as indicated in Table 3, show a rejection of the assertion that teachers posted or transferred to rural schools are susceptible to disease attacks. Out of the 260 respondents, $160(61.5 \%)$ disagreed with the above notion whilst $75(28.8 \%)$ respondents agreed with the impression. Twenty-five (25) of the respondents $(9.6 \%)$ had not taken a stand on the subject matter.

The respondents who agreed with the notion, in an interview, cited lack of potable water in most rural areas, high incidence of mosquitoes and snake bites as factors that repel teachers from rural community schools. The majority of the respondents interviewed disagreed with the impression. This was what one of the respondents had to say:

I disagree totally with that statement. There is no particular disease associated with villages, if anything at all, it is borne out of the lifestyle of the individual teacher. It is a scheme on the part of most teachers to evade posting to rural schools or get transferred to urban schools, hence create the impression that rural areas are disease endemic.

The above finding is in line with the finding that teachers who seek for transfer to urban areas often hinge their request on medical grounds and that goes to fertilise the perception that living in rural areas, comes with the danger of acquiring diseases (Akyeampong \& Stephens, 2002).

The views of the respondents were gauged on whether professional development needs, inform teachers refusal to accept posting and transfer to rural schools as well as early requests for transfer from rural schools. The questionnaire data revealed that 141 respondents representing 54\% indicate that, the quest for professional development informs teachers refusal to accept posting and transfer to rural schools as well as their early request for transfer from rural schools. A total number of 93 respondents, representing 36\%, were of a contrary view that professional development concerns keep teachers away from rural community schools whilst $26(10 \%)$ of the respondents were undecided on the subject matter.

The interview conducted with some of the respondents points to the agreement that professional development needs in terms of further studies, inform teachers reluctance to accept posting and transfer to rural schools. The following responses were gathered from the interviews conducted with the respondents: "Teachers in urban areas easily secure study leave with pay whilst their rural counterparts are mostly denied". "Teachers who stay long in rural areas, make no effort to further their education and once you find yourself in a rural area, it is difficult to secure transfer out".

These revelations suggest unfairness in granting study leave with pay to teachers. Hedges (2000) in a study opines that teachers' resistance for posting and also early request for transfer from rural areas may also result from fewer opportunities for professional advancement.

Table 3 above also embodies the view of the respondents on the tagging of teachers as "village teachers". The data show that $151(58 \%)$ of the respondents agreed that perceived ignorance about rural dwellers and branding teachers as "village teachers" contributes immensely to the reluctance of teachers to accept posting and transfer to rural schools. Seventy-nine (79) representing $30 \%$ of the respondents disagreed with the notion whilst 30 of the respondents (representing 12\%) were undecided on the issue.

The interview results show unanimity in response by the respondents that perceived ignorance and branding teachers as "village teachers" contribute to teachers' unwillingness to accept posting and transfer to rural schools. The interview elicited response such as "Even the municipal directorate officers in some instances, refer to teachers in rural areas as "village teachers" similarly, Hedges (2000) described the reluctance of teachers to accept rural posting in the following terms:

There is a profound fear among newly trained teachers with a modern individualistic outlook

that if one spends too much time in an isolated village without access to further education, the

person becomes 'a village man', This term conveys the perceived ignorance of rural dwellers in the eyes of some urban educated Ghanaians (p.32).

The opinion of respondents on teaches' desire to live in urban areas and not rural areas was measured. The responses of the respondents are shown in Table 3. The majority of the respondents 168 (64\%) agreed that teachers desire to live in large urban areas and not rural areas underlines their unwillingness to accept posting and transfer 
to rural schools. On the other hand, $80(31 \%)$ of the respondents disagreed with the statement whilst $12(5 \%)$ took no stance on the above assertion.

The interview results show that teachers have the penchant to live in urban areas because of the availability of social amenities such as electricity, potable water, and internet services, among others. This finding is in agreement with the finding of Bennell (2004), who opines that teachers want to live in large towns and not in rural areas.

The statement that the recruitment practice whereby teachers are recruited centrally by the Ministry of Education and posted to education directorates for posting to schools breeds patrimonialism, bribery and other rent-seeking behaviours by teachers to get posted to their desired schools (urban schools) attracted varied responses. A whopping majority of the respondents $182(70 \%)$ agreed to the above statement. On the other hand, 47 respondents representing $18 \%$ disagreed with the statement whilst 31 respondents $(12 \%)$ were undecided about the statement. The respondents were unanimous in opinion in an interview with a cross-section of them. A respondent had this to say:

Decentralizing recruitment of teachers to the school level will help send teachers to rural schools. Teachers who are willing to teach and committed to the profession will take up such appointments. It will curtail bribery, and other immoral practices to seek urban postings and transfers, nepotism and the undue pressure brought on officers of the municipal directorate of education to post and transfer teachers to urban schools.

This finding implies that the central recruitment system of teachers is not effective in deploying teachers to rural areas. Decentralizing recruitment of teachers according to Bennell (2004) may bring recruitment of committed and genuine teachers who have the teaching profession at heart and bring about fairness in the posting and transfer of teachers to schools.

In an interview with frontline Assistant Directors and members of the posting and transfer committee, they were asked to give the challenges they encounter in the posting and transfer of teachers to rural schools. The Assistant Director in-charge of Human Resource Management and Development mentioned political pressure, pressure from friends and relatives of teachers, family interference, health reasons, unavailability of social amenities in most rural areas such as electricity, communication network, bad road network, lack of potable water, accommodation and inability to speak the local dialect as some of the factors and challenges encountered in the posting and transfer of teachers to rural schools.

An overwhelming number of the respondents (184 representing 70.7\%) vehemently disagreed that graduate teachers and those returning from further studies are to teach in senior high schools and urban schools and not in rural schools. On the contrary, 59 respondents denoting $22.7 \%$ agreed to the above assertion. The data further show that 17 respondents representing $6.5 \%$ were undecided on the assertion that graduate teachers and those returning from further studies are to teach exclusively in senior high schools and urban schools.

The interview sessions held with some of the respondents revealed that the penchant of graduate teachers and those returning from further studies, who pursued degree programmes to teach in senior high schools and urban schools is borne out of the feeling of being above teaching at the basic level and rural schools. It is contended that some graduate teachers see it as an avenue to teach in urban areas where most senior high schools are located. This view was corroborated by the Assistant Director in-charge of planning who incidentally is a member of the posting and transfer committee of the municipal education directorate. This was what he had to say: "The majority of graduate teachers undermine the idea of coming back to teach in basic schools. This is tied to the location of basic schools, rural areas". A member of the posting and transfer committee added:

Graduate teachers think that because of their higher level of education, they are meant for senior high schools. They think that with degrees as their qualification, they should not be posted or transferred to rural areas. This is coupled with the pride or bossy nature of some graduate teachers which account for their refusal to accept posting and transfer to basic and rural schools.

The Universities and Colleges Admissions Service (UCAS, 2019), indicated that prospective primary school teachers need a Bachelor of Education (B. Ed) degree. In the case of other university degrees such as Bachelor of Arts (BA) and Bachelor of Science (BSc) degrees, a teacher's certificate or qualification is required. These requirements or qualifications, fortunately, are within the reach of most graduate teachers in the Sissala East Municipality. This trend brings to focus the need to build the base of education in the country by ensuring that highly qualified and experienced teachers are sent to teach at the basic level.

\section{Research question 2: Effects of inadequate teachers in rural schools in the Sissala East Municipality}

The data in Table 4. cover the views of respondents of the study on the effects of inadequate teachers in rural community schools. The views of the respondents reflect the use of multigrade teaching, workload, the use of unqualified teachers and the coverage of the curriculum. 
Table 4: Effects of Inadequate Teacher in Rural Schools

\begin{tabular}{|c|c|c|c|}
\hline Effect & Scale & Frequency & Percentage $\%$ \\
\hline \multirow{5}{*}{$\begin{array}{l}\text { Multigrade teaching is practiced in rural } \\
\text { schools due to inadequate teachers }\end{array}$} & Strongly Agree & 95 & 36.5 \\
\hline & Agree & 148 & 56.9 \\
\hline & Undecided & 9 & 3.5 \\
\hline & Disagree & 6 & 2.3 \\
\hline & Strongly Disagree & 2 & 0.8 \\
\hline \multirow{5}{*}{$\begin{array}{l}\text { Teachers in rural schools face high } \\
\text { workload because of insufficient teachers }\end{array}$} & Strongly Agree & 41 & 15.8 \\
\hline & Agree & 135 & 51.9 \\
\hline & Undecided & 20 & 7.7 \\
\hline & Disagree & 35 & 13.5 \\
\hline & Strongly Disagree & 29 & 11.2 \\
\hline \multirow{5}{*}{$\begin{array}{l}\text { Rural schools have high numbers of } \\
\text { unqualified teachers because of } \\
\text { inadequate qualified teachers }\end{array}$} & Strongly Agree & 90 & 34.6 \\
\hline & Agree & 125 & 48.1 \\
\hline & Undecided & 15 & 5.8 \\
\hline & Disagree & 20 & 7.7 \\
\hline & Strongly Disagree & 10 & 3.8 \\
\hline \multirow{5}{*}{$\begin{array}{l}\text { The curriculum is not covered due to the } \\
\text { shortage of teachers in rural schools }\end{array}$} & Strongly Agree & 19 & 7.3 \\
\hline & Agree & 143 & 55.0 \\
\hline & Undecided & 18 & 6.9 \\
\hline & Disagree & 55 & 21.2 \\
\hline & Strongly Disagree & 25 & 9.6 \\
\hline
\end{tabular}

\section{Source: Field Data, 2019}

The views of the respondent of the study were gauged on the practice of multigrade teaching in rural schools. Out of the 260 respondents, 251 of them agreed that multigrade teaching is practiced in rural schools due to inadequate teachers. This number of respondents represents $96 \%$. On the other hand, 9 of the respondents, representing $4 \%$, were undecided.

Interviews held with some of the respondents revealed that the majority of rural schools in the Sissala area have insufficient teachers. One of the rural school teachers had this to say: we are 8 teachers in our school who teach all the levels (KG to JHS). We had to combine the classes to enable us teach all the levels. We combined $K G 1$ and 2, primary 2 and 3, primary 4 and 5, primary 1 and 6 standing alone and 3 teachers for the JHS”

A question put to the Assistant Director in-charge of Human Resource on the likely consequences of multigrade teaching, he mentioned among others, teachers' inability to give individual pupils the needed attention, inadequate class exercises, assignments, and teachers' inability to cover the syllabuses. The above responses indicate that multigrade teaching is practiced in rural schools in the Sissala East Municipality due to inadequate teachers. This development is worrying considering its attendant effects on teaching and learning. The use of multigrade teaching without additional training and teaching materials is likely to put additional strain on teachers and reduce the quality of learning (Mulkeen, 2005). The practice of multigrade teaching leads to teacher-centred approach of teaching rather than student-centred approach which is more effective (Cornelius-White 2007).

A greater number of the respondents $240(92.3 \%)$ agreed that teachers in rural schools are confronted with high workload due to insufficient teachers. Twenty (20) respondents, representing $7.7 \%$, sat on the fence with regards to the statement.

It can be inferred from the questionnaire results that the Sissala East Municipality has inadequate teachers in its rural schools. The data further suggest that teachers in rural schools in the areas are inundated with high workload due to insufficient teachers in rural schools. In a face to face interview with one of the circuit supervisors, it was revealed that teachers in rural areas face high workload due to few numbers. He indicated that teachers found in rural schools, notwithstanding their numbers, are expected to cover the syllabus hence bring upon them stress. A study by Owusu-Acheampong \&Williams (2015) found that insufficient teachers put pressure on existing teachers hence affect their optimum performance. He further indicates that the situation affects the quality of teaching and learning since few teachers had to manage large classes in terms of supervision and control.

On the statement that rural schools have high numbers of unqualified teachers because of inadequate teachers, elicited varied responses from the respondents. A whooping number of the respondents 215 (representing 82.7\%) agreed with the statement whilst $30(11.5 \%)$ of the respondents disagreed with the claim. Fifteen (15) of the respondents, representing $5.8 \%$, were undecided on the statement. The data suggest that there is a high number of unqualified teachers as well as inadequate teachers in rural schools in the Sissala East Municipality. In an interview with the Assistant Director in-charge of quality, a question as to why the high numbers of untrained teachers in rural schools revealed that untrained teachers are recruited purposely to fill vacancies. He indicated that most 
teaching vacancies are found in rural areas due to the unwillingness of most trained teachers to accept posting and transfer to rural schools. This finding is serious and can affect the future of the teaming number of pupils in rural schools. The shortage of teachers according to Monk (2007), lead to the engagement of inexperienced and untrained teachers in schools. These teachers lack the skills in the art of teaching hence affecting teaching and learning in immeasurable terms.

The views of the respondents on the statement that the coverage of school curriculum is threatened with the inadequate teachers in rural schools, led to the following responses; 162 respondents representing $62 \%$ agreed that the school curriculum is greatly affected in terms of coverage with the shortage of teachers in rural schools. Eighty (80) respondents disagreed with the assertion whilst the remaining $18(7 \%)$ respondents out the 260 respondents took no stance on the statement. The shortage of teachers in rural areas affects the teaching of critical subjects such as special education, science and mathematics (Monk, 2007). Similarly, Echazarra and Radinger (2019) indicated that the curriculum is severely affected when handled by teachers with little subject-specific training.

\section{Research question 3: Strategies for posting and transfer of teachers to rural community schools}

Table 5 contains questionnaire data on the views of the respondents concerning the strategies of sending teachers to rural schools. These strategies include the recruitment of teachers from targeted rural areas, giving teachers financial incentives, organising induction for new teachers, forced deployment of teachers and siting of teacher training institutions and universities in rural areas to give will-be teachers the feel of rural living hence prepare them for rural schools.

Table 5: Strategies for Posting and Transfer of Teachers to Rural Schools

\begin{tabular}{|c|c|c|c|}
\hline Strategies & Scale & Frequency & Percentage $\%$ \\
\hline \multirow{5}{*}{$\begin{array}{l}\text { Recruiting teachers from targeted rural } \\
\text { areas help in sending and retaining } \\
\text { teachers in rural community schools }\end{array}$} & Strongly Agree & 32 & 12.3 \\
\hline & Agree & 40 & 15.4 \\
\hline & Undecided & 26 & 10.0 \\
\hline & Disagree & 98 & 7.7 \\
\hline & Strongly Disagree & 64 & 24.6 \\
\hline \multirow{5}{*}{$\begin{array}{l}\text { Giving financial incentives to rural } \\
\text { teachers help attract and retain them } \\
\text { in rural areas }\end{array}$} & Strongly Agree & 146 & 56.2 \\
\hline & Agree & 74 & 28.5 \\
\hline & Undecided & 10 & 3.8 \\
\hline & Disagree & 22 & 8.5 \\
\hline & Strongly Disagree & 8 & 3.1 \\
\hline \multirow{5}{*}{$\begin{array}{l}\text { Induction of new teachers to the policies } \\
\text { and culture of the school district } \\
\text { encourage teachers to accept posting and } \\
\text { transfer to rural community schools }\end{array}$} & Strongly Agree & 36 & 13.8 \\
\hline & Agree & 122 & 46.9 \\
\hline & Undecided & 56 & 21.5 \\
\hline & Disagree & 38 & 14.6 \\
\hline & Strongly Disagree & 8 & 3.1 \\
\hline \multirow{5}{*}{$\begin{array}{l}\text { Force posting and transfer of teachers is } \\
\text { the way forward to staffing rural } \\
\text { community schools }\end{array}$} & Strongly Agree & 28 & 10.8 \\
\hline & Agree & 42 & 16.2 \\
\hline & Undecided & 14 & 5.4 \\
\hline & Disagree & 78 & 30.0 \\
\hline & Strongly Disagree & 98 & 37.7 \\
\hline \multirow{5}{*}{$\begin{array}{l}\text { Siting of teachers training institutions and } \\
\text { university campuses in rural areas afford } \\
\text { teacher trainees the feel of rural living and } \\
\text { teaching hence prepare them for rural } \\
\text { schools }\end{array}$} & Strongly Agree & 68 & 26.2 \\
\hline & Agree & 98 & 37.7 \\
\hline & Undecided & 27 & 10.4 \\
\hline & Disagree & 43 & 16.5 \\
\hline & Strongly Disagree & 24 & 9.2 \\
\hline Total & & 260 & 100.0 \\
\hline
\end{tabular}

\section{Source: Field Data, 2019}

The views of the respondents on recruiting teachers from targeted rural areas will enhance the posting and transfer of teachers to rural schools revealed that 162 respondents disagreed with the idea. This number represents $62 \%$ of the respondents for the study. Seventy-two (72) respondents $(28 \%)$ however lauded the idea. Meanwhile, 26 respondents representing $10 \%$ took no stance on the assertion that the strategy of sending teachers to rural schools is by recruiting teachers from targeted rural areas. In a face-to-face interview with some of the respondents, it emerged that the strategy is not sustainable. One of the respondents said:

Human beings by nature are unpredictable and teachers are no exception. Teachers with a rural background may accept posting and transfer to rural areas but after teaching for few years may seek transfer to urban areas. Some could refuse posting and transfer to rural schools. Every teacher wants to enjoy the advantages and luxury associated with urban areas.

The above finding points to the ineffectiveness of targeted recruitment of teachers from rural areas. This 
finding is in agreement with the finding of Azam (2001), who found in a study that educated members of a disadvantaged minority group may view their education as a means of social mobility and may have no desire to remain in rural communities once qualified.

The views of the respondents on the efficacy of financial incentives in attracting and retaining teachers in rural schools were gauged. It emerged from the study that 220 respondents bought into the idea that heavy financial investment for rural teachers in the form of incentives, is one of the surest ways or strategies of attracting and retaining teachers in rural schools. This number of respondents represent an overwhelming percentage of $84.7 \%$. A handful of the respondents, 30 representing 11.6\%, disagreed with the statement whilst 10 respondents, representing $3.8 \%$, were undecided about the statement. It came to light that out of the interviews conducted with a cross-section of the participants, financial incentives have the potentials of attracting and retaining teachers in rural schools.

The above finding corroborates the findings of researchers such as Liu, Johnson and Peske (2004) and Lowe (2006) who argued that in Massachusetts State in the United States of America and Mozambique respectively, financial incentives in the form of bonuses were effective in attracting and retaining teachers in rural schools.

The questionnaire administered gathered the views of the respondents on the effects of induction of new teachers in retaining them in rural schools. The data in Table 5 above amply demonstrate that the respondents agreed to the claim that the induction of a new teacher to the policies and culture of a school and community in which a school is located helps retain them in schools. One hundred and fifty-eight (representing 60.7\%) respondents agreed to the claim whilst 46 respondents (representing 17.7\%) disagreed with the claim. A total of 56 respondents, (denoting 21.5\%) took no stand regarding the claim. A teacher shared his personal experience with regards to induction in the following terms:

Induction in my own experience is paramount in retaining new teachers in schools. It gives a teacher the feel of belongingness and acceptance in his or her new school environment. When I first step foot in my current school, the verbal cheers and smiles that greeted me alone assured me of a school in which I was welcomed with opened arms hence my willingness to stay in this school.

This finding indicates that induction in general, especially for new teachers is key in retaining teachers in schools, especially rural schools. The provision of first-hand information regarding a school or a community to new teachers is paramount in attracting and retaining them. It prepares them for the work ahead and makes them feel special, welcomed, and appreciated. It also brings about positive attitudes and a sense of belonging among teachers (Lowe, 2006).

The views of the respondents were also solicited on the use of force in the posting and transfer of teachers as contained in Table 5 above. The data indicate that the majority of the respondents $176(68 \%)$ abhor the idea of forced posting and transfer of teachers to rural school locations. Only 70 respondents representing $27 \%$ bought into the idea of the use of force as a strategy in staffing rural schools with the required numbers of teachers. Fourteen respondents $(5 \%)$ were undecided on the use of force in posting and transfer of teachers to rural schools. One of the few respondents who endorsed the idea of forced posting and transfer of teachers to rural schools indicated the following:

Forced posting and transfer of teachers in our education directorate is the way forward. We are told that once you accepted to be a teacher, you should be prepared to accept posting and transfer to schools where your services are most needed. If posting and transfer of teachers are based on choice, no teacher will accept rural posting and transfer.

In an interview with one of the respondents, he objected to the idea of forced deployment of teachers to rural schools. He summed up his view in an adage that "you can force a horse to the riverside but you cannot force the horse to drink the water".

The above finding is in agreement with the research findings of Garson (1998) and Samuel (2002). These writers argued that forced posting and transfer of teachers to rural schools have the potentials of affecting the quality of teaching and high attrition of teachers. Kelleher (2008) on the other hand, indicated that centralising deployment of teachers is one way to realising the effectiveness of forced deployment of teachers. Mulkeen (2005) on his part prescribed careful management practices as the antidote to the forced deployment of teachers to rural schools.

The respondents' views on the siting of teacher training institutions and university campuses in rural areas as a strategy in attracting and retaining teachers in rural schools elicited the following responses. It emerged from the data that 166 respondents $(64 \%)$ bought into the idea that siting of teachers training institutions and university campuses in rural areas will afford teacher trainees a feel of rural living and teaching hence prepare them for rural schools. On the contrary, 67 respondents $(26 \%)$ objected to the aforementioned idea. Only 27 respondents (representing 10\%) were undecided on the idea put forward.

The interviews that were conducted with some of the respondents affirmed the acceptance of the idea of siting teacher training institutions and university campuses in rural areas to give will-be teachers the feel of rural living, 
do away with negative perceptions of teaching in rural schools and prepare them for rural schools. This finding is absolutely in line with the finding of Hudson and Hudson (2008), who found in a study, the aforementioned ideas put forward by the respondents.

The views of the frontline assistant directors and members of the posting and transfer committee at the municipal education directorate were sought in an interview on strategies to enhance the posting and transfer of teachers to rural schools. The following responses were gathered: provision of decent accommodation, granting of study leave, payment of T\&T and transfer grants, awarding hardworking rural teachers, provision of incentives such as television sets, payment of allowances and recommending rural teachers for Best Teacher Awards. A member of the posting and transfer committee remarked: "Any teacher who accepts posting to a rural area for four (4) years should be one rank above his or her colleagues". These strategies are a regurgitation of research findings by researchers such as Liu, Johnson and Peske (2004), Lowe (2006) and Maranto and Shuls (2013).

It was unanimous in response in an interview with frontline assistant directors and members of the posting and transfer committee of the Sissala East Municipal Education Directorate that pupil enrolment informs the posting and transfer of teachers to schools in the municipality. Pupil-teacher ratio according to Kadzamira (2006) should form the basis of posting and transfer of teachers to schools. Emphasis should not be placed on the number of classrooms available.

\section{Conclusion}

The situation of no challenge in the posting and transfer of teachers to schools emerged when teachers willingly accept posting and transfer without any form of resistance. A challenge free situation of posting and transfer of teachers occurs, regardless of teacher qualification, financial ability, prevailing social conditions in a school community but contingent on the dictates of the teaching profession, accept posting and transfer to whatever school location (rural or urban) without resistance or evasion.

Findings of this study point to acute challenges in the posting and transfer of teachers in the Sissala East Municipality. Teachers in the Municipality resist and evade posting and transfer to rural community schools based on poor housing, qualification obtained, rent-seeking behaviour, perceived ignorance of conditions in rural areas and tagging teachers in rural areas as 'village teachers. It could, therefore, be concluded, based on the findings, that the Sissala East Municipal Education Directorate is challenged in the posting and transfer of teachers to rural schools.

\section{References}

Akyeampong, K. \& Stephens, D. (2002). Exploring the backgrounds and shaping of beginning student teachers in Ghana: Toward greater contextualisation of teacher education. International Journal of Educational Development, 22(3-4): 262-274.

Azam, J., P. (2001). The Redistributive state and conflicts in Africa. Journal of Peace Research, 38(4), 429-444.

Barry, E. T., \& Terence, J. T. (1976). Transfer systems: The opinions of queensland teachers. Evaluation series. Queensland Department of Education, Brisbane (Australia).

Bennell, P. (2004). Teacher motivation and incentives in Sub-Saharan Africa and Asia. Knowledge and skills for development, Brighton. Retrieved June 01, 2019, from http://citeseerx.ist.psu.edu/viewdoc/download?doi=10.1.1.539.6931\&rep=rep1\&type=pdf

Cornelius-White, J. (2007). "Learner-centered teacher-student relationships are effective: A meta-analysis." Review of Educational Research 77(1) 113-143.

Daniel, A., K. (1994). Improving the deployment of teachers: The Ghanaian experience UNESCO: International Institute for Educational Planning 7 - 9 rue Eugène-Delacroix, 75116 Paris

Echazarra, A. \& Radinger, T. (2019). Learning in rural schools: Insights from Pisa, Talis and the literature. OECD Education Working Paper No. 196. Retrieved 03, 2019, from www.oecd.org/edu/workingpapers

Garson, P. (1998). Teacher deployment: What went wrong? In K. Fieldgate, (Ed.). Helping to establish a culture of learning and teaching in South Africa. Guateng, South Africa: Education Africa.

Hassan, H., H. (2016). The effects of employees transfer on secondary schools performance in Zanzibar: A Case Study at South District, Unguja. (Master's dissertation, University of Tanzania, Tanzania). Retrieved: September 24, 2018. Website: http://repository.out.ac.tz/1580/1/HASSAN_HUSSEIN_HASSAN.pdf

Hedges, J. (2000). The Importance of posting in becoming a teacher in Ghana. (University of Sussex Centre for International Education MUSTER Discussion Paper No. 13

Hudson, P. \& Hudson, S. (2008). Changing pre-service teachers' attitudes for teaching in rural schools. Australian Journal of Teacher Education, 33(4) 67-75.

Jackson, K.C., \& Bruegmann E. (2009). Teaching students and teaching each other: The importance of peer learning for teachers. American Economic Journal: Applied Economics, 1(4), 1-30.

Jason, A. G., Susanna, L. \& Nathaniel, N. (2012). Involuntary teacher transfers and student achievement: Examining equity and efficiency. Retrieved: September 24, 2018. 
https://cepa.stanford.edu/sites/default/files/involuntary\%20transfers $\% 20$ submission\%20version\%20FULL.PDF

Johnson, R., B., Onwuegbuzie, A., J. \& Turner, L. A. (2007). Toward a definition of mixed methods research. Journal of Mixed Methods Research, 1(2), 112-133.

Kadzamira, E., C. (2006).Teacher motivation and incentives in Malawi. Malawi: Centre for Educational Research and Training University of Malawi.

Kelleher, F. (2008). Primary school teacher deployment: A comparative study. Commonwealth Secretariat Marlborough House, Pall Mall London SW1Y 5HX United Kingdom.

Liu, E., Johnson, S. M. \& Peske, H. G. (2004). New teachers and the Massachusetts signing bonus: The limits of inducements. Educational Evaluation and Policy Analysis, 26(3), 217-236.

Lowe M., J. (2006). Rural education: Attracting and retaining teachers in small schools. The Rural Educator, 27(2), 28-31. Retrieved May $29, \quad$ from http://citeseerx.ist.psu.edu/viewdoc/download?doi=10.1.1.501.1526\&rep=rep1\&type=pdf

Lynne, M. H., \& Nancy, C. (1985). Involuntary teacher transfer: An intervention strategy for professional development final report. Ontario Inst. for Studies in Education, Toronto.

Maranto, R. \& Shuls, V., J. (2013). How do we get them on the farm? Efforts to improve rural teacher recruitment and retention in Arkansas. Retrieved June 18, 2019, from https://files.eric.ed.gov/fulltext/EJ1000101.pdf

Melinda, S., K. (2000). Teacher transfer policy and the implications for equity in urban school districts. Paper presented at the annual: meeting of the American Educational Research Association (New Orleans, LA, April 24-28, 2000)

Moleni, M., C. \& Ndalama, C., J., L. (2004). Teacher Absenteeism and attrition in Malawian primary schools: A case study of four districts draft report. A collaborative study between: Centre for Educational Research and Training (CERT) and Malawi Institute of Education (MIE)

Monk, D. (2007) "Recruiting and retaining high-quality teachers in rural areas", The Future of Children, 17(1), 155-174. Retrieved November 06, 2019, from https://files.eric.ed.gov/fulltext/EJ795884.pdf

Mulkeen, A. (2005). Teachers for rural schools: A challenge for Africa. UNESCO Seminar on education for rural people in Africa - policy, lessons, options and priorities. Addis Ababa.

Noor, F., Ishaque, M., Lodhi, F., \& Memon, A. (2012). Effects of teacher's transfer on school system. Interdisciplinary Journal of Contemporary Research in Business, 4(2), 593-614. Retrieved July 12, 2019, from https://journal-archieves19.webs.com/593-617.pdf

Owusu-Acheampong, E \& William, A. A. (2015). Dearth of teachers in rural basic schools: Implications on human resource development in the Amenfi West District, Ghana. British Journal of Education, 3(1), 32-43.

Patton, Q. M. (2002). Qualitative research and evaluation methods. London, Sage Publications.

Samuel, M. (2002). Working in the rain: Pressures and priorities for teacher education curriculum design in South Africa: A case study of the University of Durban-Westville. International Journal of Educational Development, 22, 397-410.

Terrell, S. (2011). Mixed-methods research methodologies. The Qualitative Report, 17(1), 254-280. Retrieved July 14, 2019, from https://files.eric.ed.gov/fulltext/ EJ973044.pdf 